\title{
Observation of Fish Dissemination Pattern on Madura Coastal Using Segmentation of Satellite Images
}

\section{Citra Nurina Prabiantissa, Achmad Basuki, Wahjoe Tjatur Sesulihatien}

\author{
Department of Information and Computer Engineering \\ Graduate Program of Engineering Technology \\ Politeknik Elektronika Negeri Surabaya \\ Jl. Raya ITS, Sukolilo, Surabaya, 60111, Indonesia \\ Telp: 62315947280 Fax: 62315946114 \\ E-Mail : citranurina@gmail.com, basuki@pens.ac.id, \\ wahyu@pens.ac.id
}

\begin{abstract}
Almost traditional fishermen still use manual methods to catch fish that rely on experience in fishing and information among fellow fishermen. This method is not effective for maximizing fish production. A good pattern or strategy is needed to increase fish production. In determining dissemination pattern of fish, it can be predicted from physical parameters such as temperature, salinity, chlorophyll, turbidity, total suspended solids, and colored dissolved organic matter using the Landsat 8 images. This research area is on the Island of Madura Coast. The pattern is determined by using Lagrange Interpolation and clustering using K-Means. The results of the study of the pattern of fish dissemination were then validated with data from the Dinas Kelautan dan Perikanan Jawa Timur. The results between fish patterns and validation data in 2015 showed similarities in January, February, March, May, June, July, August, September. In 2016, results between fish patterns and validation data showed that similarities in July, August, September, and December. In 2017, results between fish patterns and validation data showed similarities in November. 2015 has the most similarities between the patterns and validation data and the least similarity are 2017.
\end{abstract}

Keywords: Fish Dissemination, K-Means, Lagrange Interpolation, Segmentation, Satellite Images

\section{INTRODUCTION}

Indonesia is an archipelagic country with more than $50 \%$ of its territory is waters. From the condition of the Indonesian state which is an archipelago, waters are a very useful natural resource. The geographical conditions by the people who use it as a place for transportation, recreation, or as a job site. Indonesia which is located in the equatorial area which is fertile both land and sea so that it has abundant biological and non-biological resources. 
Because the fertile waters of most people manage it in the field of fisheries and the cultivation of marine plants. Fisheries is one of the sectors that determine the economy in Indonesia. Therefore, fish harvests in Indonesia also need to be improved. So far, fishermen still use traditional methods to catch fish, relying on experience in fishing and information among fellow fishermen. This method is not effective for maximizing fish production. A good pattern or strategy is needed to increase fish production.

Locations or fishing grounds are still determined based on traditional fishing methods based on experience and information from other fishermen [1]. Fish are very vulnerable and change very quickly in accordance with a dynamic environment and global change. This change causes it to be increasingly difficult for fishermen to determine fishing grounds [2].

The choice of location for fishing is generally based on the species we want to culture and the technology used, but in some instances, the sequence can be reversed. The existence of restrictions on one of these factors, the characteristics of suitable waters will limit the selection of other factors. Some considerations that need to be considered in determining the location are technical conditions which consist of physical, chemical, and nontechnical parameters in the form of market share, security, and human resources [3]. One of the mistakes in developing cultivation is an unsuitable aquatic environment. In order for cultivation to develop properly, it is necessary to have appropriate water condition data. The northern coastal area of the island of East Java, which is around the Madura strait which is used as a place of research, is an area that has the appropriate criteria for fishing. So that to see its development from year to year can use the science of remote sensing. The use of remote sensing can cover a wide range of areas at the same time. Remote sensing can be used to detect high sea surface temperatures and brightness levels quickly, effectively, efficiently and can cover a wider area compared to direct measurements that require more costs and energy. The prospect of sea fishing in the future is still very good to increase the income of coastal communities.

In previous studies, researchers only determined the potential of fishing grounds using parameters. In this study, observations were made to observe the dissemination patterns of fish from one place to another for three years using Landsat 8 satellite data.

\section{RELATED WORKS}

D. Fitrianah, et al [4] has made a research about the identification of fish potential zones based on the data mining approach. The spatio-temporal clustering method is used to identify clusters from zones with the largest amount of fishing data, where the data has been integrated with Sea Surface Temperature and Sea Surface Chlorophyll data obtained from MODIS satellite images. The results of the integration data are then used for training data in the classification process. During the classification process using the $\mathrm{k}$ nearest neighbor (KNN) classification method. The results provide $87.11 \%$ 
accuracy which indicates that the framework can be used effectively to determine Potential Fishing Zone (PFZ). For the validation framework, the authors compare their performance with heuristic rules taken from a knowledge-based expert system model from the data of Sea Surface Temperature and Sea Surface Chlorophyll. The results show that the framework that has been made outperforms heuristic rules from a knowledge-based expert system model.

S. Nurdin, et al [5] proposed about parameters used to identify fish is by combining parameters of sea surface temperature (SST) and chlorophyll-a (chl-a). These parameters are used to determine productivity in the marine environment. Chl-a is an oceanographic parameter to determine productivity in the sea because in Chl-a there is a pigment, which is the biomass index of phytoplankton. SST is a parameter that controls the physiology of living organisms and affects the growth of phytoplankton. The results of the study are from processing satellite image data with SST and Chl-a features that use multiple regression statistical models and GIS techniques which are easy and useful methods to determine and map the potential of R.Kanagurta fishing grounds. The method is reliable and can do fast forecasting to help fishermen make decisions and reduce fishing time.

A. Ruiz-Verd, et al [6] proposed about fishing zone cannot be determined when cloudy weather is due to the limitations of the sensor to penetrate the clouds. However, there is a high demand from fishermen in India to provide information about areas that have the potential to catch fish during cloudy weather or during periods of monsoons. Therefore, the use of altimetry products is used to validate fish forecasting using satellite multisensors using the parameters SST, Chl-a, NPP, SSHA, EKE, and fishing data. The results of the study were cold water with high nutrition suitable for fishing. This can be seen by the Chl-a image which has more information than the SST parameter which is the main indicator for fishing. For EKE and SSHA parameters, the second indicator has the dominant role for area-level distribution that has the potential to catch fish.

Syariz, et al [7] proposed Sea Surface Temperature is one of the marine environmental factors that are important for determining changes in the marine environment and ecological activity. To detect sea surface temperature on Poteran Island in Madura, Landsat 8 Thermal Infrared Sensor (TIRS) is used and use band 10 and band 11. The result is that Landsat 8 with thermal sensors has good results for calculating sea surface temperature. In the calculation using an algorithm, it shows that there is optimal performance when using band 10 and band 11. By using this algorithm, monitoring sea surface temperature can use satellite data with fairly good accuracy. 


\section{ORIGINALITY}

This research uses a new approach to determine fish dissemination patterns in the Madura Strait using GeoTIFF-based Landsat 8's satellite images. In previous studies, the parameters used to determine the presence of fish use only 2 or 3 parameters. But in this study using a combination of 6 parameters. The parameters used are temperature, salinity, chlorophyll, turbidity, total suspended solids, and colored dissolved matter which is an oceanographic parameter for determines the presence of fish. Not only a combination of 6 parameters used, but also see the movement of fish every month for three years. Observation of the study was conducted from 2015 to 2017. This research was carried out to help fishermen know the area that has a lot of fish potential. Previously, fishermen still used traditional methods to get fish. With this system, it is expected that productivity from the fisheries sector for communities around the coast will increase.

\section{SYSTEM DESIGN}

The design system created below contains the processing of satellite data to determine fish dissemination patterns. Diagram system consists of 5 phases consisting of data, pre-processing, extraction features, overlay and segmentation, and observation. The results of this research are presented in the last phase (observation) in the form of mapping of fish dissemination patterns.

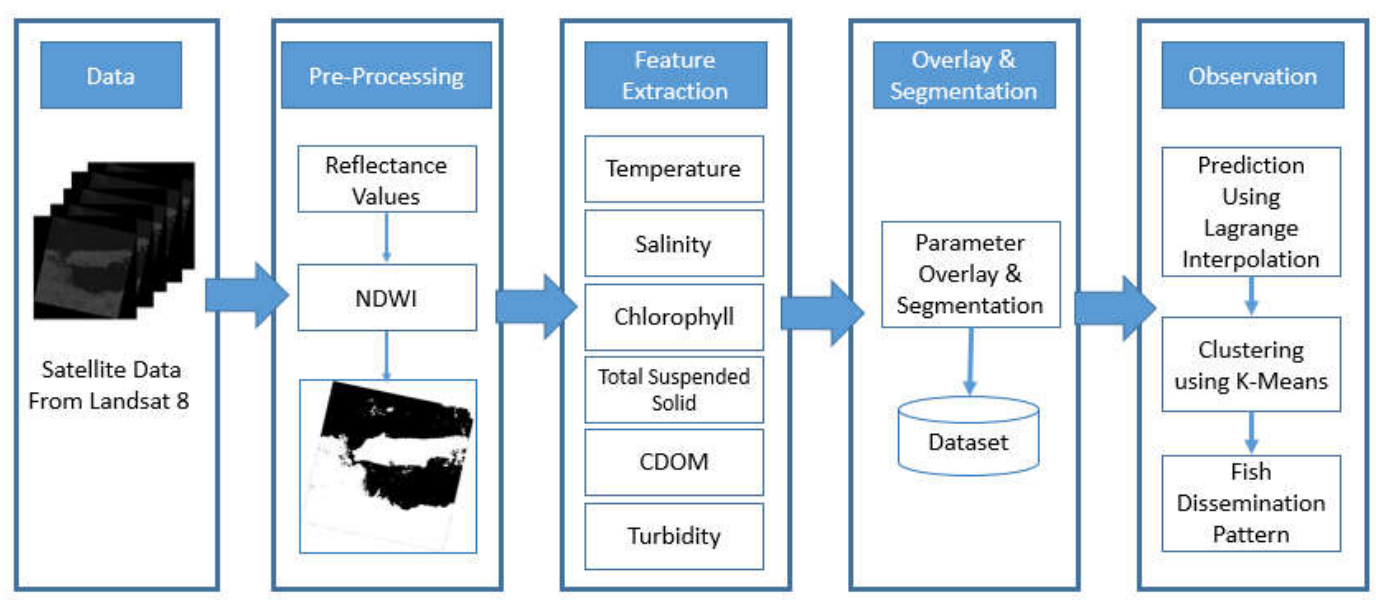

Figure 1. System Design

\subsection{Satellite Data}

The data used in the study are Landsat 8's satellite data which is downloaded directly on the NASA USGS Explorer website. This data has a GeoTIFF format consisting of 11 images, consist of bands 1 through band 11 and information about satellite data is presented in the form of metadata. Every month, NASA releases the latest data 2 times at the beginning of the month and the end of the month. From 2 times data collection by NASA is taken the best data every month. In this study, the data used are time series 
from January to December 2015, 2016, and 2017. The amount of data used is 36 satellite image data. The area uses the East Java region, especially the coastal area of the Madura Island.



Figure 2. Landsat 8 Satellite Data

\subsection{Pre-processing}

In the Preprocessing phase, the Normalized Difference Water Index is carried out. This process aims to separate land and sea areas in the image. This is needed in order to focus more on the area to be studied. Before process NDWI, the first step is to change the value of the digital number (DN) from the image into a reflectance value using the following formula [8] :

$$
\rho \lambda^{\prime}=\text { MpQcal }+\mathrm{Ap}
$$

Whereabout $\rho \lambda$ ' is the results of previous processing, without taking angle correction. $\rho \lambda$ ' does not contain a correction for the sun's angle. Qcal is the pixel value (DN). $\mathrm{Mp}$ is rescaling constant (REFLECTANCE_MULT_BAND_x, where $\mathrm{x}$ is the band used). Ap is additive constant (REFLECTANCE_ADD_BAND_x, where $\mathrm{x}$ is the band used). Mp and Ap values are obtained from the metadata in one package with data from the NASA website. After that, calculate using the NDWI formula using a combination between band combinations namely band 3 (green) and band 5 (Near Infrared) on Landsat 8, the calculation formula is as follows [8] :

$$
\mathrm{NDWI}=\frac{\mathbb{R} s s a-\mathrm{R} s s 5}{\mathrm{R} s z a+\mathrm{R} s s 5}
$$

Where Rss is the result of processing a digital number that has been converted to reflectance value and divided by 3.14 .

\subsection{Feature Extraction}

Feature Extraction is done by extracting 6 parameters, there are : chlorophyll, temperature, salinity, turbidity, colored dissolved organic matter (CDOM), and total suspended solids (TSS). Each parameter is processed to find out the existence of fish. After that initial segmentation is done. The following is an explanation of each parameter: 


\subsubsection{Temperature}

One important factor for fishing using satellite images is temperature [9]. Temperature is also important for the survival of organisms [10]. Gases such as $\mathrm{CO}_{2}$ and $\mathrm{O}_{2}$ for photosynthesis are also influenced by temperature. This gas easily dissolves at low temperatures which affect photosynthesis. The heat received from sunlight causes temperatures on the surface to vary based on changes in time. This change can occur several days, months, years, or in a long period of time.

Temperature is the outermost part of an object and the first element that can be taken from thermal satellite images. On Landsat 8, band 10 and band 11 are bands that have thermal waves. The first step to determine the surface temperature is to change the digital number to spectral radians. Doing this requires a band 10 . Here is how to change the digital number to spectral radians [7]:

$$
\mathrm{L} \lambda=\mathrm{M} \lambda \mathrm{xQcal}+\mathrm{A} \lambda
$$

$\mathrm{L} \lambda$ is top of atmosphere spectral radiance. $\mathrm{M} \lambda$ is band-specific multiplicative rescaling factor. Qcal is the digital number and $A \lambda$ is a bandspecific additive scaling factor. After that, convert the calculation results into the form of brightness temperature using the following formulas [7] :

$$
T=\frac{k 2}{\operatorname{In}\left(\frac{K 1}{2 \lambda}+1\right)}
$$

$\mathrm{K} 1$ and $\mathrm{K} 2$ values can be seen in the metadata obtained when downloading satellite data from USGS Explore website.

\subsubsection{Chlorophyll}

Chlorophyll parameters have a strong correlation with certain waters [4]. Chlorophyll is an indicator of phytoplankton levels in the aquatic environment. This is useful for showing the fertility level of an aquatic environment. In Indonesian waters, the chlorophyll content is $0.19 \mathrm{mg} / \mathrm{m}^{3}$ on average during the western season and $0.21 \mathrm{mg} / \mathrm{m}^{3}$ in the western season. In marine waters, this chlorophyll index can be linked to fish production or describe the level of productivity of fishing grounds because it is used as a measure of the number of phytoplankton in certain waters [20].

In this study, to extract chlorophyll values from Landsat 8 satellites using an algorithm:

$$
[\mathrm{Chl}-\mathrm{a}]=446 \frac{R 660}{R 440}-0.55
$$

In the algorithm above, numbers 560 and 440 have wavelengths used. Before using an algorithm, the digital number must be changed to reflectance value. 


\subsubsection{Salinity}

Salinity is defined as the amount of weight of salt dissolved in 1 liter of water, usually expressed in units of \%o [19]. Measuring salinity is an important biological factor that must be measured to find out underwater life. Salinity detection is also useful for determining circulation and pollution models in coastal areas for irrigation. In addition, this measurement is to determine the balance between evaporation and precipitation and can be identified as priority measurement [11]. By using Landsat-8 satellite imagery, identification of salinity levels can be done using the salinity algorithm [12]. The equation are :

$$
\text { Salinity }=10^{\left(-0.141 \times \log _{10}(c p)+3.45\right)}
$$

(Cp) is the coefficient of attenuation of the light entering the surface of the water. (Cp) can be calculated using the following equation:

$$
\mathrm{Cp}=10^{\left[0.70 \times M N D C I^{2}+0.96 \times N N D C I^{2}+1.14 \times N N D C I-0.25\right]}
$$

MNDCI (Maximum Normalized Difference Carbon Index) is calculated using the following equation:

$$
\mathrm{MNDCI}=\left[\frac{[\operatorname{Rss}(555)-\max (\operatorname{Rss}(412) \operatorname{Rss}(443), \operatorname{Rss}(490))]}{[\operatorname{Rss}(555)+\max (\operatorname{Rss}(412) \cdot \operatorname{Rss}(443) \cdot \operatorname{Rss}(490))]}\right]
$$

Rss is the result of processing a digital number that has been converted to reflectance value and divided by 3.14. Figures 412, 443, 490, and 555 are the value of wavelength.

\subsubsection{Total Suspended Solid}

Suspended solids are all solid substances (sand, mud, and clay) or particles suspended in water and can be living components (biotics) such as phytoplankton, zooplankton, bacteria, fungi, or dead components (abiotic) such as detritus and inorganic particles. Suspended solids are places where heterogeneous chemical reactions take place, and function as the precipitating material and can hinder the ability to produce organic substances in waters.

Penetration of sunlight to the surface and deeper parts do not take place effectively due to being blocked by suspended solids, so photosynthesis does not take place perfectly. The distribution of suspended solids in the sea is influenced, among others, by inputs originating from land via river flow, or from the air and displacement due to suspended deposits due to erosion [13]. For processing the TSS algorithm can use the following formula [8]:

$$
\mathrm{TSS}=31.42 *(\log \operatorname{Rrs} 2 / \log \operatorname{Rrs} 4)-12.719
$$


Rss is the result of processing a digital number that has been converted to reflectance value and divided by 3.14 .

\subsubsection{Turbidity}

Turbidity is one of the factors that can affect the lives of fish and other organisms. This parameter determines water quality directly which has an influence on the penetration of light entering the ocean waters. The increase and decrease in the level of turbidity have an effect on the biological components under the sea. For processing the turbidity algorithm can use the following formula [14]:

$$
\text { Turbidity }=380.32 \operatorname{Rrs}\left(\lambda_{\mathrm{B} 4}\right)-1.7826
$$

Rss is the result of processing a digital number that has been converted to reflectance value and divided by 3.14 . $\lambda_{\mathrm{B} 4}$ is the band used on Landsat 8 , namely band 4 .

\subsubsection{Colored Dissolved Organic Matter}

CDOM is an important factor for knowing water quality. CDOM influences the aquatic ecosystem. Many satellites have remote sensing algorithms for CDOM development, such as SeaWiFS, MODIS-Aqua, and MERIS for coastal areas. Landsat is designed for terrestrial observations for monitoring high spatial resolution sea color constituents $(30 \mathrm{~m})$. The quality of Landsat 8 has increased compared to Landsat 7. It is, therefore, appropriate to use Landsat 8 to extract CDOM parameters. The following algorithm is used [15] :

$$
\operatorname{CDOM}(\lambda)=\mathrm{A}(\lambda) \frac{\text { In } 10}{\text { Pathlength }}=A(\lambda) \times 230.3
$$

\subsection{Overlay and Segmentation}

The overlay is a process of combining several parameters, there are temperature, salinity, chlorophyll, CDOM, turbidity, and total suspended solids. In the previous process, the initial segmentation was done. Madura region is divided into 3 colors, which are appropriate area (green), quite an appropriate area (orange), and not appropriate are (red) for the presence of fish. From the segmentation results, each region gave different weighting values. Merging 6 parameters uses calculations like in table 1 where weighting is multiplied by scale. After calculating the weighting, the results of the initial segmentation have different values. For this reason, a normalization process is carried out where the segmentation value is converted to a value of $0-1$ [21]. The following is the weighting table used in the explanation above: 
Table 1. Weighting Parameter

\begin{tabular}{|c|c|c|c|c|c|c|c|c|c|c|}
\hline \multirow[b]{2}{*}{ Parameter } & \multirow[b]{2}{*}{$\begin{array}{l}\mathrm{w} \\
\mathrm{e} \\
\mathrm{i} \\
\mathrm{g} \\
\mathrm{h} \\
\mathrm{t}\end{array}$} & \multicolumn{3}{|c|}{ Appropriate } & \multicolumn{3}{|c|}{$\begin{array}{c}\text { Quite } \\
\text { Appropriate }\end{array}$} & \multicolumn{3}{|c|}{ Not Appropriate } \\
\hline & & Criteria & $\begin{array}{l}\mathrm{S} \\
\mathrm{c} \\
\mathrm{a} \\
\mathrm{l} \\
\mathrm{e}\end{array}$ & $\begin{array}{l}\mathrm{S} \\
\mathrm{c} \\
\mathrm{o} \\
\mathrm{r} \\
\mathrm{e}\end{array}$ & Criteria & \begin{tabular}{|l|}
$\mathrm{S}$ \\
$\mathrm{c}$ \\
$\mathrm{a}$ \\
$\mathrm{l}$ \\
$\mathrm{e}$ \\
\end{tabular} & \begin{tabular}{|l|}
$\mathrm{S}$ \\
$\mathrm{c}$ \\
$\mathrm{o}$ \\
$\mathrm{r}$ \\
$\mathrm{e}$ \\
\end{tabular} & Criteria & \begin{tabular}{|l}
$\mathrm{S}$ \\
$\mathrm{c}$ \\
$\mathrm{a}$ \\
$\mathrm{l}$ \\
$\mathrm{e}$ \\
\end{tabular} & $\begin{array}{l}\mathrm{S} \\
\mathrm{c} \\
\mathrm{o} \\
\mathrm{r} \\
\mathrm{e}\end{array}$ \\
\hline Temperature $\left({ }^{\circ} \mathrm{C}\right)$ & 3 & $26-32$ & 5 & $\begin{array}{l}1 \\
5\end{array}$ & $20-25$ & 3 & 9 & $>32 \&<20$ & 1 & 3 \\
\hline Turbidity (NTU) & 3 & $1.0-10$ & 5 & $\begin{array}{l}1 \\
5\end{array}$ & $\begin{array}{c}10.0- \\
14.0\end{array}$ & 3 & 9 & $<1 \&>14$ & 1 & 3 \\
\hline TSS (mg/l) & 3 & $<20$ & 5 & $\begin{array}{l}1 \\
5\end{array}$ & $20-80$ & 3 & 9 & $>80$ & 1 & 3 \\
\hline CDOM (nm) & 3 & $0.3-0.5$ & 5 & $\begin{array}{l}1 \\
5 \\
\end{array}$ & $0.6-2.0$ & 3 & 9 & $<30 \&>2.0$ & 1 & 3 \\
\hline Salinity (\%o) & 3 & $31-32$ & 5 & $\begin{array}{l}1 \\
5\end{array}$ & $29-31$ & 3 & 9 & $>32 \&<29$ & 1 & 3 \\
\hline $\begin{array}{c}\text { Chlorophyll } \\
\left(\mathrm{mg} / \mathrm{m}^{3}\right)\end{array}$ & 3 & $>=0.14$ & 5 & $\begin{array}{l}1 \\
5\end{array}$ & $\begin{array}{c}0.07- \\
0.14\end{array}$ & 3 & 9 & $<0.07$ & 1 & 3 \\
\hline
\end{tabular}

From the results of the normalization value, then the second segmentation is done by dividing the area of fish's presence into 3 areas as in the initial segmentation. The difference between the first and second segmentation is, in the first segment, indicating the existence of fish using each parameter. While the second segment uses a combination of 6 parameters that have been weighted.

\subsection{Observation of Fish Movement Pattern}

In this step, the dataset containing the results of the overlay and segmentation is applied by Lagrange Interpolation algorithm to predict the movement of fish for four weeks from each month. This pattern is taken by taking the pixel value of the green region data on the segmentation results. The following is pseudocode of Lagrange Interpolation [16]:

INPUT: vector $x$; vector $y=f(x)$; a point to evaluate $z$

OUTPUT: Pz Lagrange Interpolation $P(x)$ evaluated at $z$

Step 1 Initialize variables. Set $P z$ equal zero. Set $n$ to the number of pairs of points $(x, y)$. Set $L$ to be the all ones vector of length $n$.

Step 2 For $i=1$ to $n$ do ...

Step 3 For $j=1$ to $n$ do

Step 4. If $i \neq j$ then $L i=\left(\begin{array}{ll}z & x j\end{array}\right) /\left(\begin{array}{ll}x i & x j\end{array}\right)^{*} L i$ 


$$
\text { Step } 5 \mathrm{Pz}=L i{ }^{*} y i+\mathrm{Pz}
$$

Step 6 Output Pz. Stop.

After the prediction process using Lagrange Interpolation, data every week in one month has been obtained. This data is used to observe fish movement patterns. Fish movement patterns are calculated using the KMeans Clustering algorithm with the closest distance searching method using Euclidean Distance. The distance is then drawn with the closest cluster. This research using the k-means algorithm because this method is very popular with its ability to cluster huge data [23] like Landsat 8 data which has an image resolution of $7000 \times 7000$. This method is widely used because it is effective in the use of various problems [17]. Following are the steps in applying the K-Means algorithm:

1. Calculate the distance of all data to the existing centroid

2. Compare the distance between centroids and placing data on clusters that have the closest distance to the centroid

3. Calculate the new centroid through the members in each cluster

4. Repeat steps 2 and 3 until the centroid doesn't move

\section{EXPERIMENT AND ANALYSIS}

The experiment in this study was made into 4 parts, namely the initial segmentation process of each parameter, overlay and segmentation, and prediction using Lagrange Interpolation pattern determination for observation.

\subsection{Initial Parameter Segmentation}

The first process that is done is preprocessing. This process is useful to mark the desired region of interest, which is to separate the land and sea area and then segment it with white (land) and black (sea). The following is a picture of the NDWI results:

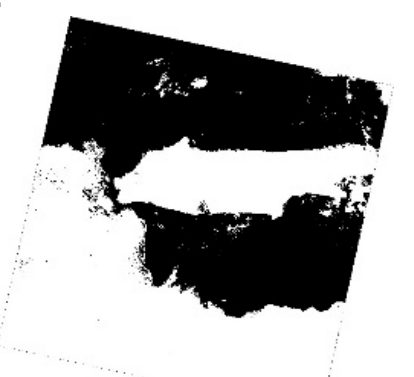

Figure 3. NDWI result

After preprocessing, the initial segmentation of the parameters is needed for feature extraction and knowing how much influence the parameters have on the presence of fish. Segmentation is done by dividing 
the Madura coastal area into 3 regions: suitable, quite suitable, and not suitable for the overall parameters. This is done to find out the existence of the fish's starting position. The division of the region uses weighting carried out by the researcher so that the treatment for each parameter is the same. Normalization is also applied to make the values that were varied by each parameter to range 0 - 1 . After some of these processes are done, the results of the initial segmentation are displayed as follows:

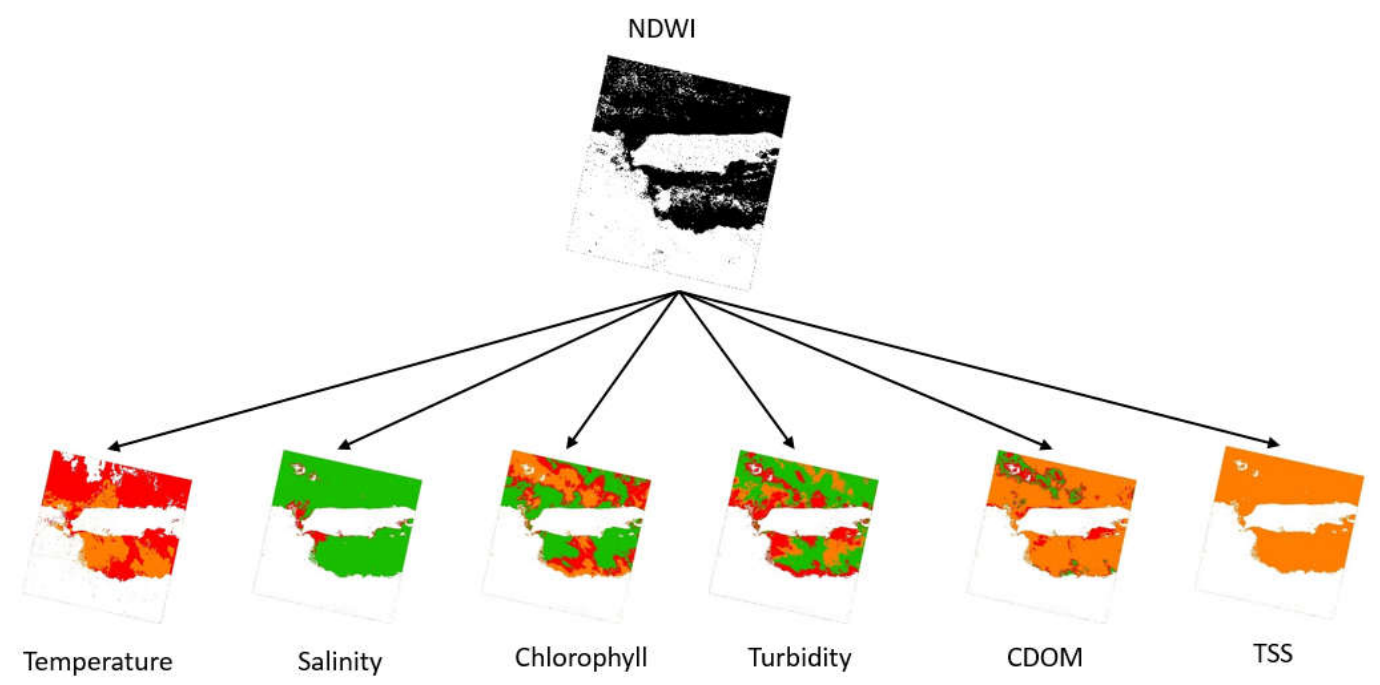

Figure 4. Initial Segmentation Process

Illustration in figure 4 shows the whole of the initial segmentation process. The black and white picture above shows a picture of the NDWI results. NDWI is a segmentation to separate land and sea areas. The NDWI result image is then used as a basis for forming the segmentation of 6 parameters. After going through the calculation process with the formula in section 4.3 about feature extraction, then the results are displayed on 6 images, that is segmentation of temperature, salinity, cdom, turbidity, tss, and chlorophyll.

\subsection{Overlay and Segmentation}

The overlay is a combination of all parameters that have been carried out by initial segmentation. The image is merged into one to later be taken the required features. After overlaying, then the second segmentation is then carried out. The second segmentation is carried out to determine the position of the fish after merging all parameters. The results of the overlay and segmentation 2015 are shown as follows : 


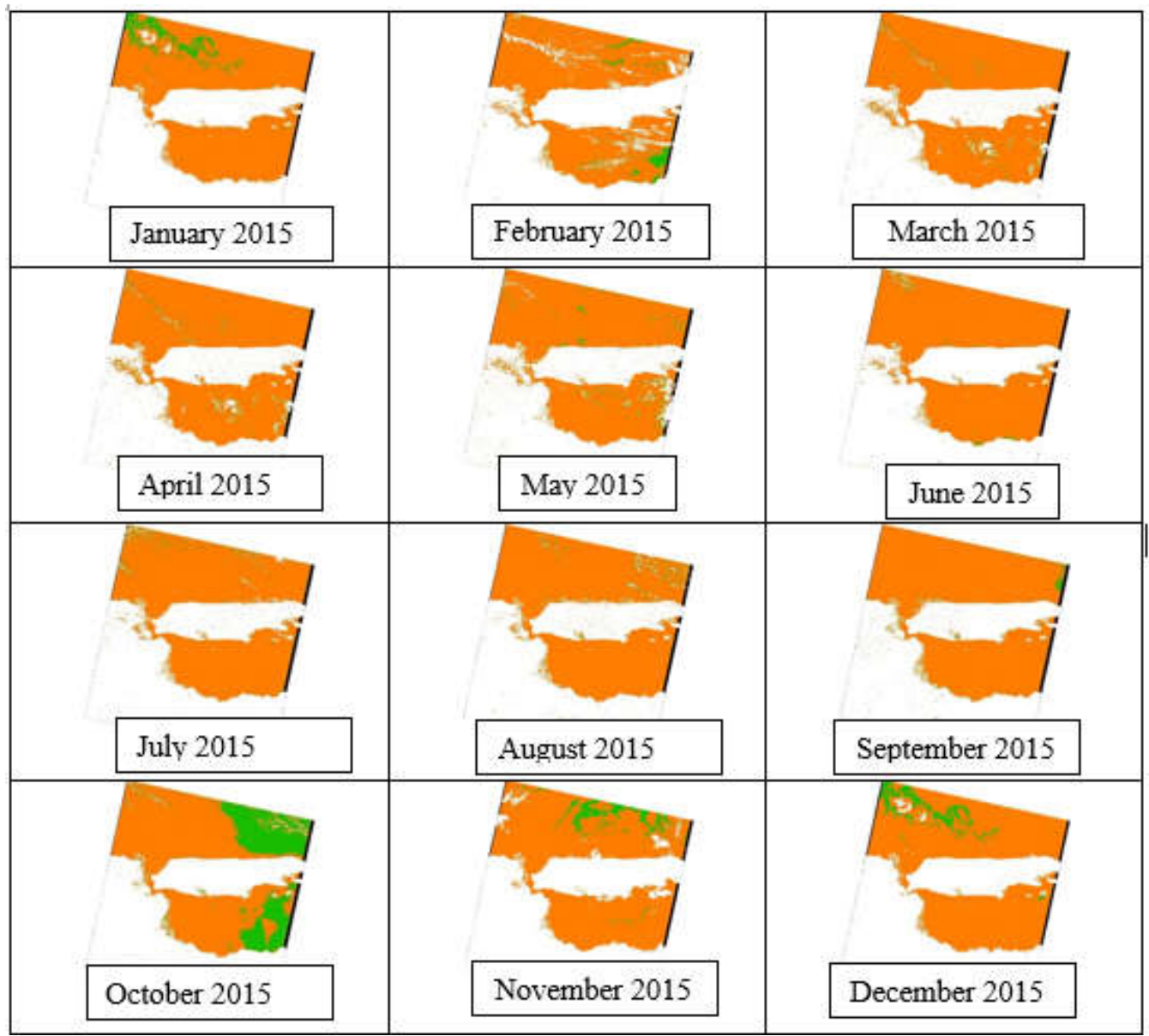

Figure 5. Overlay and Segmentation Result 2015

The second overlay and segmentation are done on the whole data every month in 2015, 2016, and 2017. In figure 5 shows an example of the results of overlay and segmentation in 2015 from January to December. In the picture, there are some green areas that show a lot of fish in the area. While the orange color indicates not too much fish in the area. The green area will be used as a reference for the next process.

\subsection{Prediction using Lagrange Interpolation}

Time series data is data taken monthly from January to December from 2015 to 2017. The time series data used in this study was taken from NASA's USGS Explore website. To find out the fish movement from one place to another it takes data every week. Data predictions every week are calculated using the Lagrange Interpolation algorithm. An illustration of the process of applying the Interpolation Lagrange is shown in figure 6: 


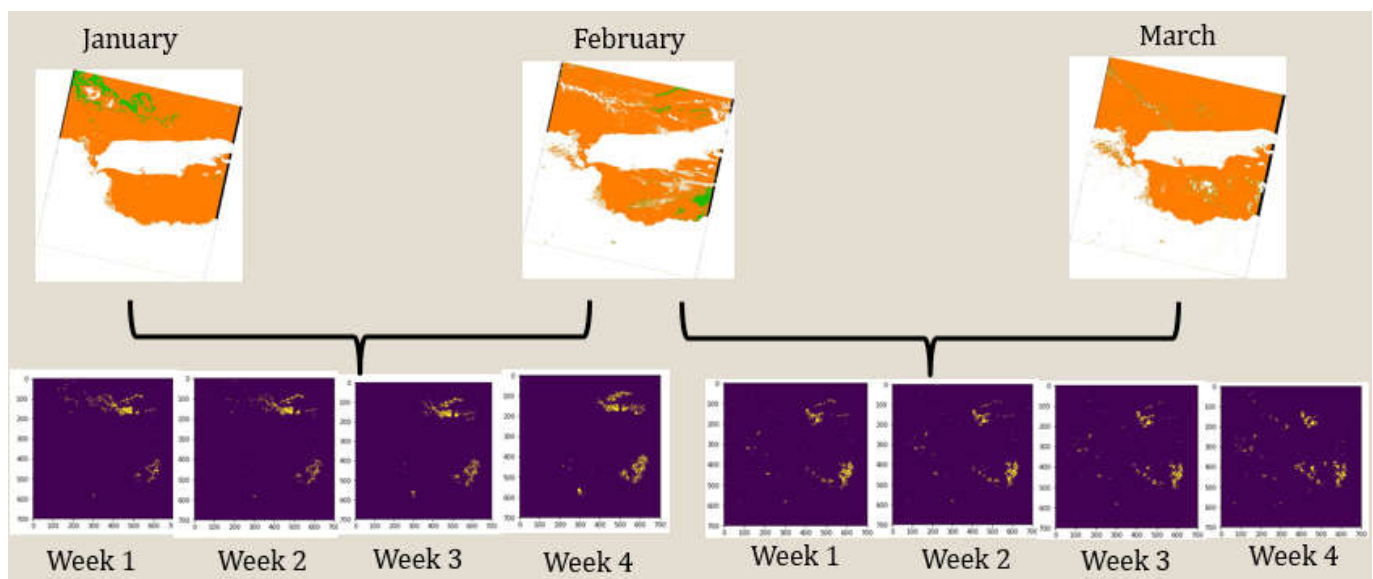

Figure 6. Illustration of prediction using Lagrange Interpolation

In figure 6, there is a prediction of the existence of fish between each month in one year using the Lagrange Polynomial algorithm and the results of the overlay. The previous overlay results from show green segmentation (suitable) and orange (quite suitable). The segmentation used is a green area, indicating that there is a fish in that place. The results of applying the algorithm can be seen between January and February or February and March obtained images of the presence of fish (shown in yellow) from week 1 to week 4.

\subsection{Observation of Fish Movement Patterns}

The pattern of movement of fish from one place to another has several influencing factors, both biological and chemical factors. The 6 parameters used in this study represent these two factors. Fish always migrate from one place to another, this indicates that the position of existence will always change [18]. In process 5.3 above, data has been obtained every week within 3 months. After a prediction for each week in one year, then the clustering process is carried out to find out the pattern of moving fish in accordance with the location of the adjacent centroid. The location of the centroid indicates a group of fish that move from one place to another.

For determining fish dissemination pattern uses K-Means Clustering algorithm. Distance is calculated using Euclidian Distance and uses the number $\mathrm{k}=2$. Several patterns starting from week 1 are clustered and the closest distance is searched. The closest distance is then given a line. The results of fish movements are shown in the following figure: 


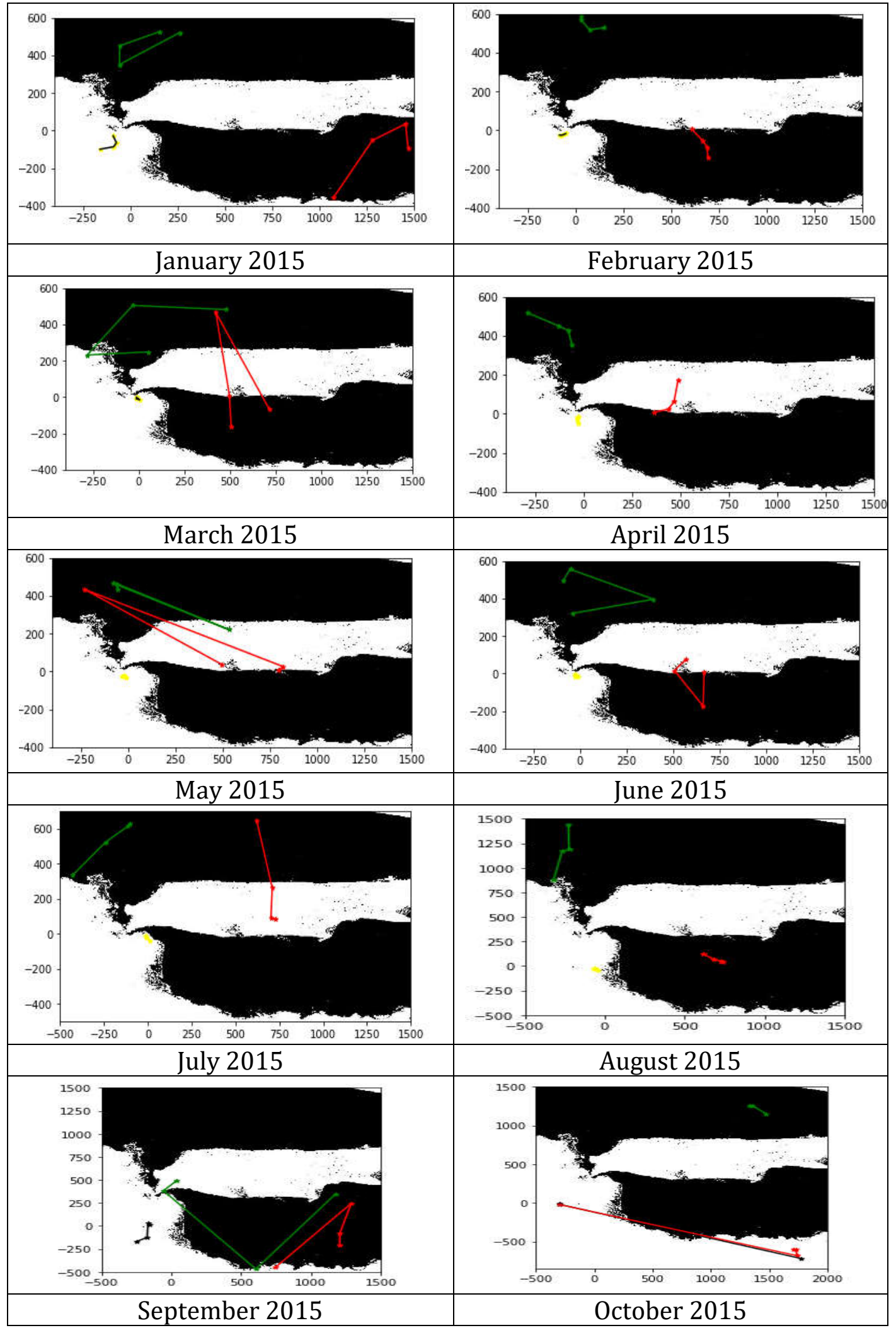




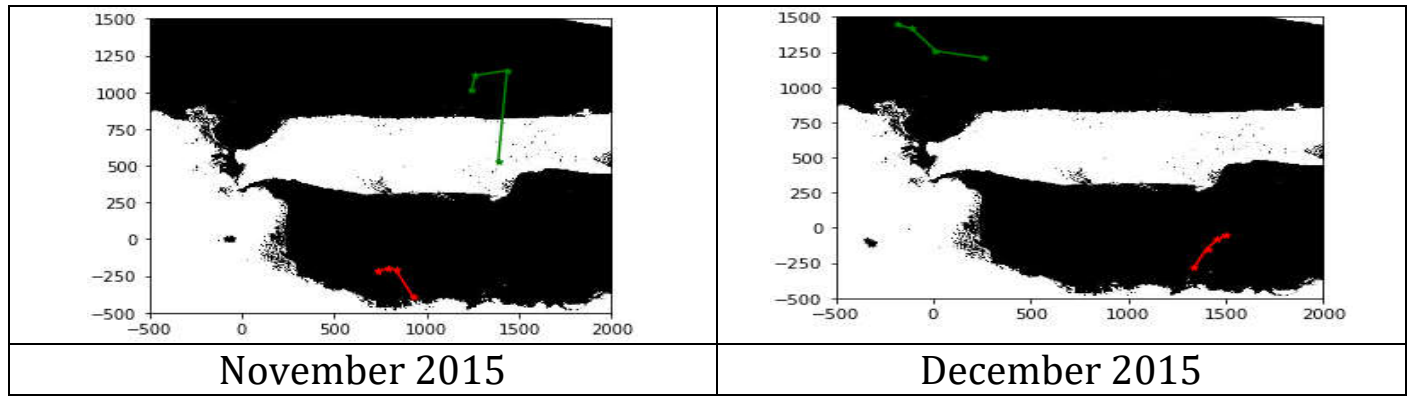

Figure 7. Fish Dissemination Pattern 2015

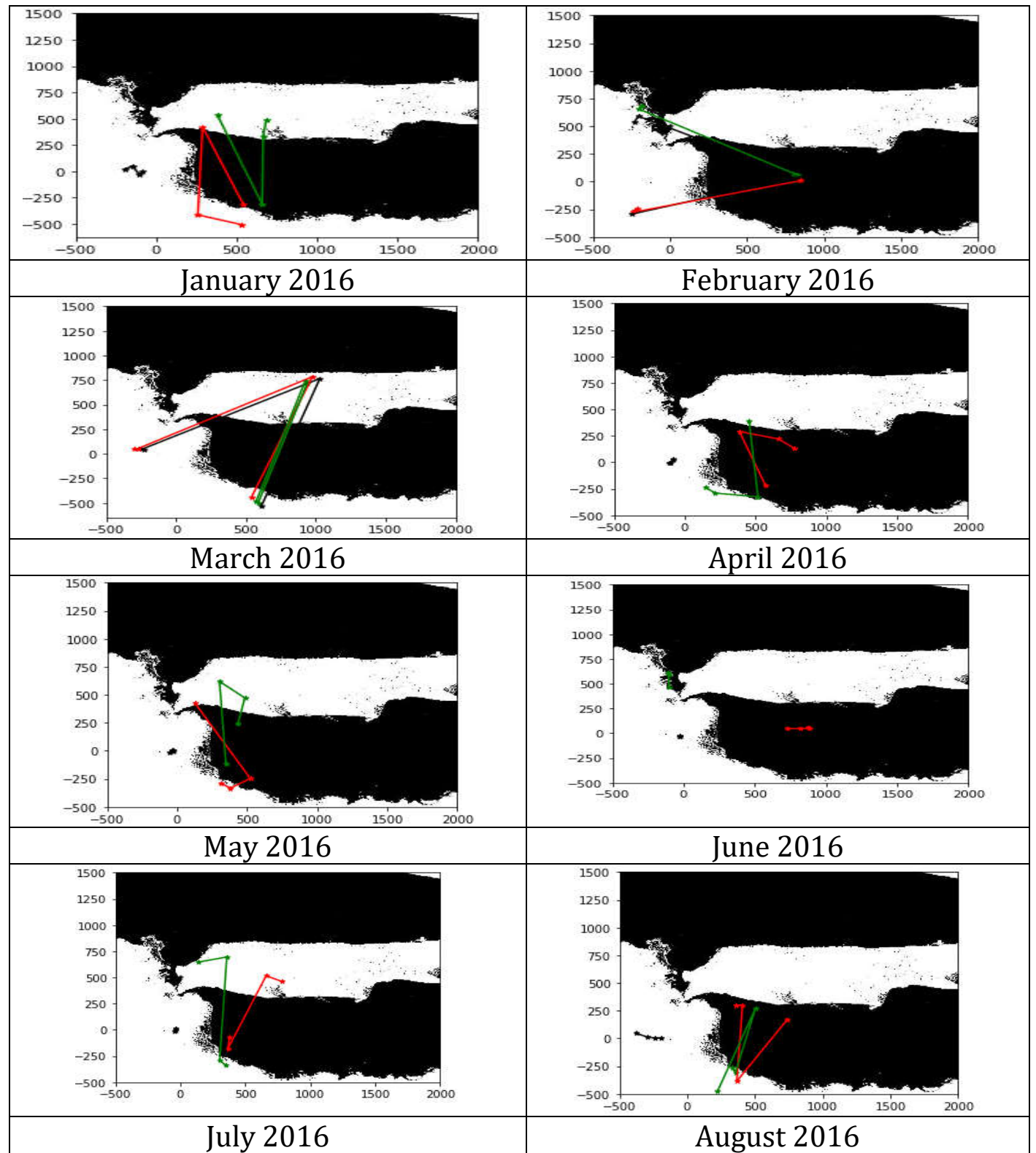






Figure 8. Fish Dissemination Pattern 2016

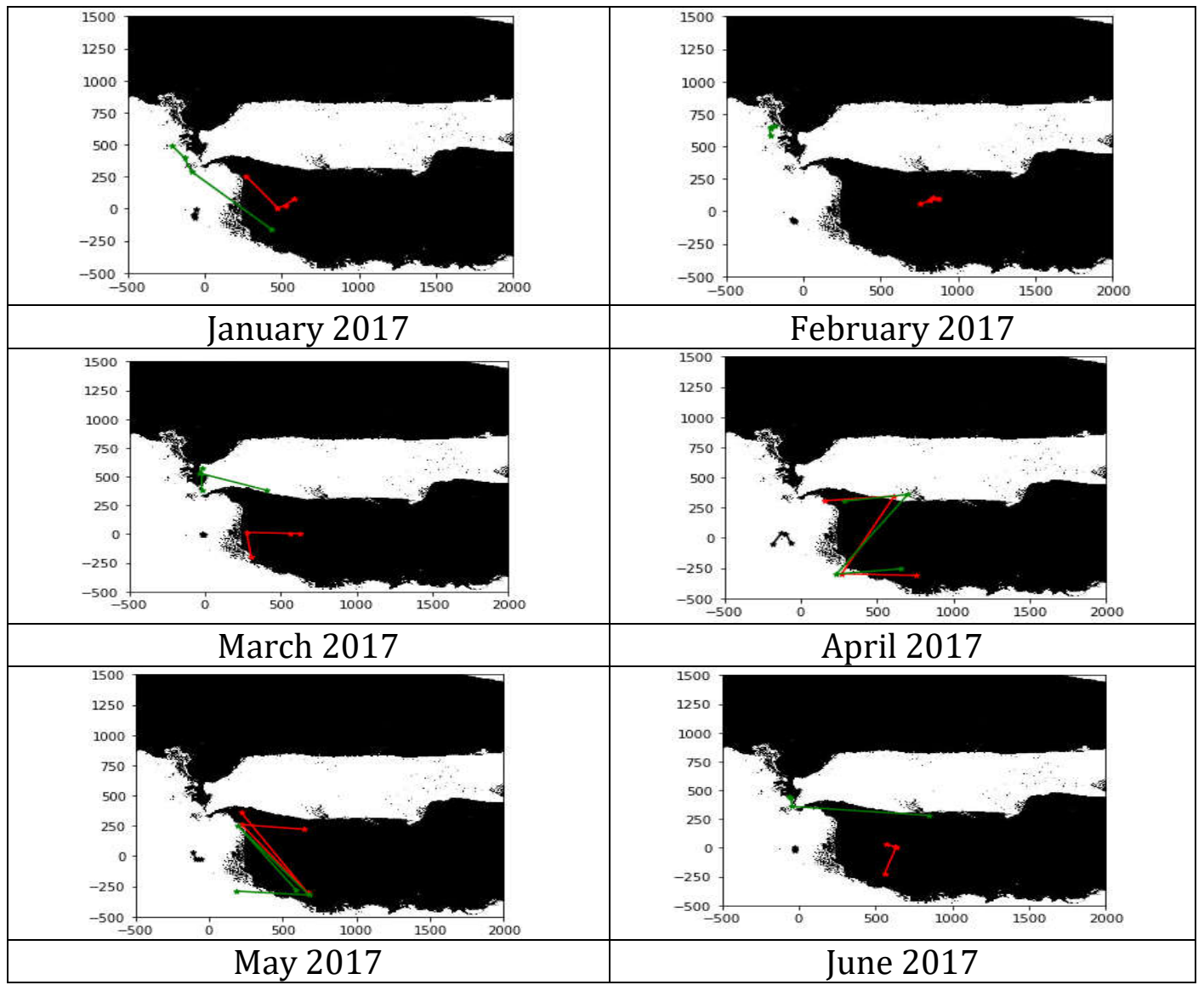




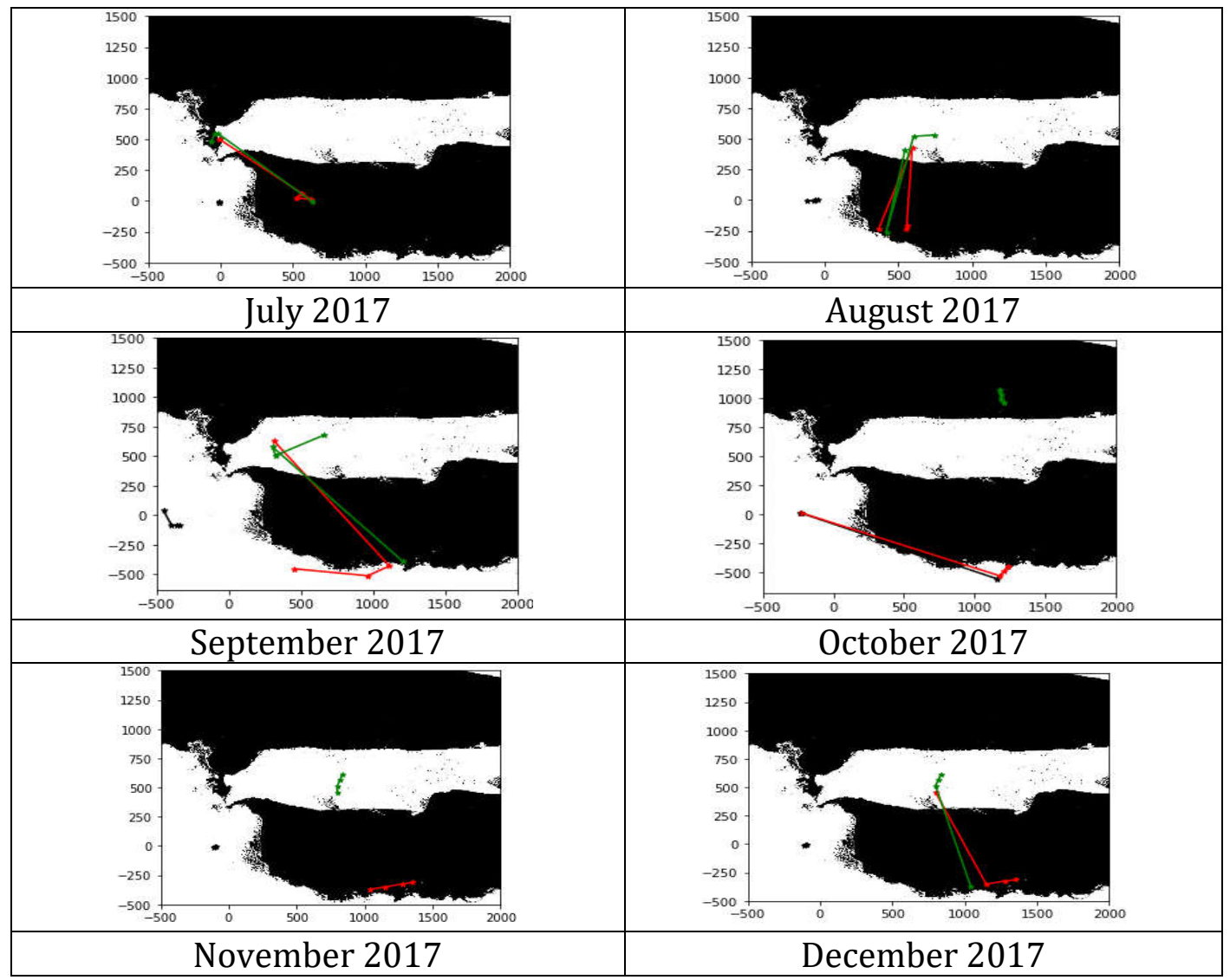

Figure 9. Fish Dissemination Pattern 2017

The map above shows a number of fish movement patterns that occurred from 2015 to 2017. Each month has a different movement pattern. $\mathrm{K}$-Means has a disadvantage that is the result of each running program has different results [22]. In this research, the best selection of many patterns was used. The red and green lines in the picture show the movements of the fish that occurred in that month. From this pattern, it shows the frequency of fish movements more often in that place for 1 month, until the following month where most of them change from the previous pattern. This means that the pattern of fish is always changing because of the nature of fish that always migrate from one place to another. From the red and green lines found the location of fish near the island of Madura. The results of the map are presented in the following table: 
Table 2. Result From Map

\begin{tabular}{|l|l|l|l|}
\hline \multicolumn{1}{|c|}{ Months } & \multicolumn{1}{|c|}{ Region (2015) } & \multicolumn{1}{c|}{ Region (2016) } & \multicolumn{1}{c|}{ Region (2017) } \\
\hline January & Bangkalan, Sumenep & Bangkalan, Sampang & Bangkalan \\
\hline February & Bangkalan, Sampang & Bangkalan, Sampang & Sampang \\
\hline March & Bangkalan, Sampang & Bangkalan, Sampang & Bangkalan \\
\hline April & Bangkalan & Bangkalan & Bangkalan, Sampang \\
\hline May & Bangkalan, Sampang & Bangkalan & Bangkalan \\
\hline June & Bangkalan, Sampang & Bangkalan, Pamekasan & Bangkalan, Sampang \\
\hline July & Bangkalan, Pamekasan & Bangkalan & Bangkalan \\
\hline August & Bangkalan, Pamekasan & Bangkalan, Sampang & Bangkalan \\
\hline September & $\begin{array}{l}\text { Bangkalan, Sampang, } \\
\text { Pamekasan, Sumenep }\end{array}$ & Sampang & Bangkalan \\
\hline October & Pamekasan & Sampang & $\begin{array}{l}\text { Bangkalan, Sampang, } \\
\text { Pamekasan }\end{array}$ \\
\hline November & Bangkalan, Pamekasan & Sampang, Pamekasan & $\begin{array}{l}\text { Sampang, Pamekasan, } \\
\text { Sumenep }\end{array}$ \\
\hline December & $\begin{array}{l}\text { Bangkalan, Sampang, } \\
\text { Pamekasan }\end{array}$ & $\begin{array}{l}\text { Sampang, Pamekasan, } \\
\text { Sumenep }\end{array}$ & Sampang, Pamekasan \\
\hline
\end{tabular}

The results from the 2015 to 2017 table above contain areas on Madura Island according to patterns on maps (Figures 7, 8, and 9). The results from the table are then validated with captured fish data from Dinas Kelautan dan Perikanan Provinsi Jawa Timur. The following shows a graph of 2015 catch fish data: 


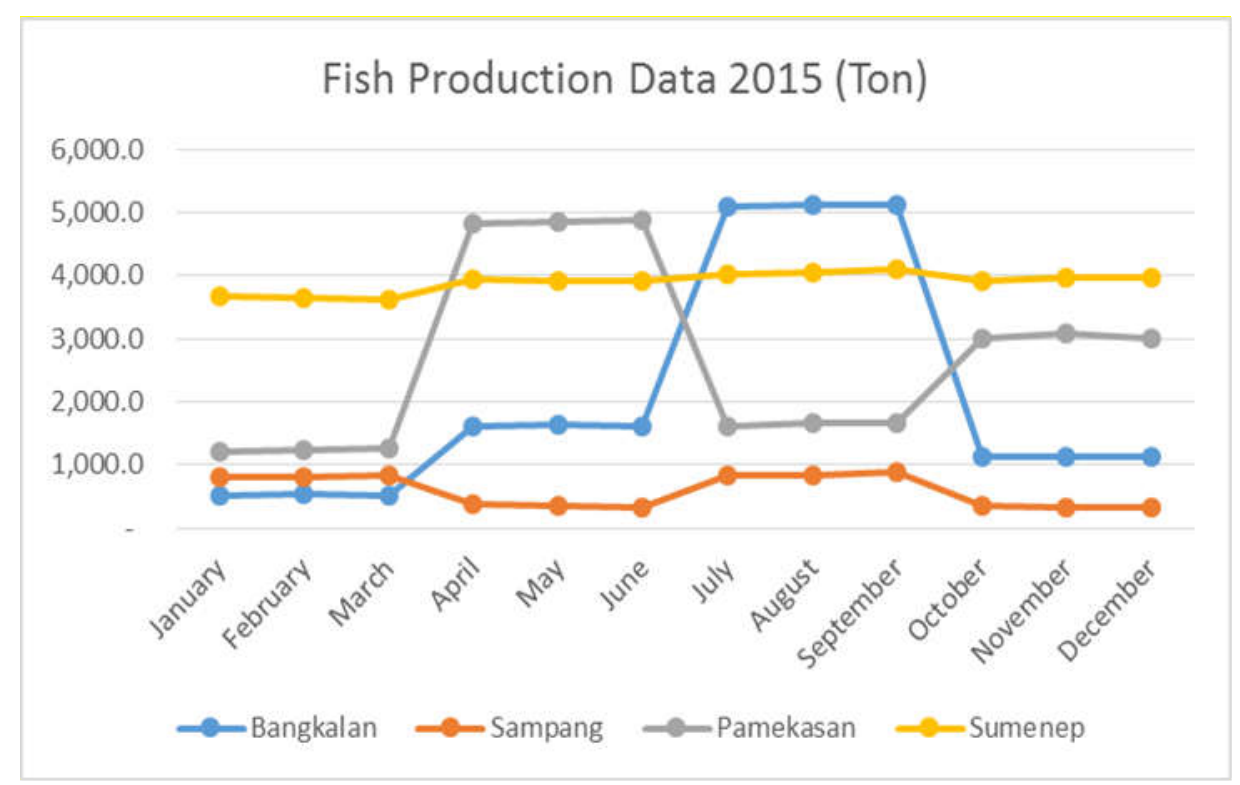

Figure 10. Fish Production Data 2015

Data in Figure 10, in the first quarter (January, February, and March), Sumenep became the region with the most fish production, which according to the map, the pattern that dominated was the Bangkalan area with those 3 months. But in January, Sumenep's prediction became one of the regions that had the most fish production according to validation data. In the second quarter (April, May, June) the most fish production was Sampang. These predictions match the results of the pattern on the map in May and June. For the third quarter (July, August, September), the results of maps and fish production have similarities, that is Bangkalan as the area that has the most fish production. In the fourth quarter (October, November, and December), fish production in this three months was the most achieved by the Sumenep region with a range of 4.000 tons. But the results of the pattern do not match the results of production. The following shows a graph of Fish Production Data in 2016 which will be compared with the results of the fish pattern according to the map in table 2 : 


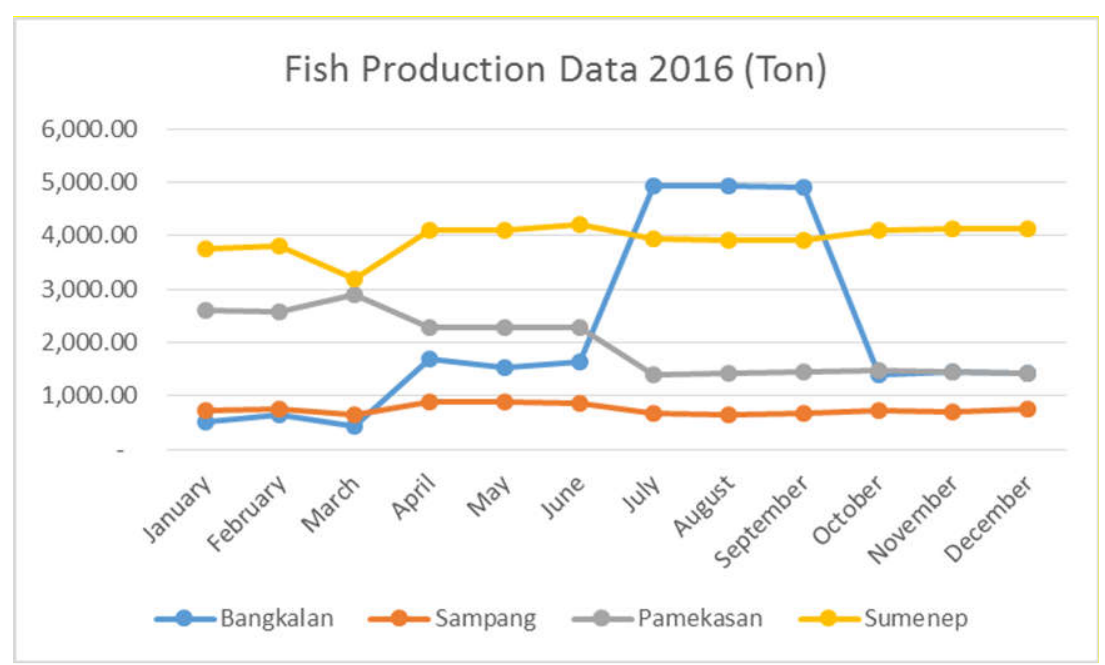

Figure 11. Fish Production Data 2016

In the graph above, in the first quarter (January, February, and March), Sumenep showed the most fish production. This is not suitable in accordance with the results of the pattern on the map that shows Bangkalan and Sampang as areas that should have a lot of fish production. In the second quarter (April, May, June), it was still like the first quarter where the fish pattern did not match the fish production. Sumenep still has the most fish production with an average amount of 4.000 tons. Whereas the pattern shows that the Bangkalan and Pamekasan areas are regions with large numbers of fish. In the third quarter (July, August, September), fish patterns and production had the same results, namely Bangkalan being the region with the most fish production. In the fourth quarter (October, November, and December), there were similar patterns and yields in December in the Sumenep area. The following shows a graph of Fish Production Data in 2017 which will be compared with the results of the fish pattern according to the map in table 2:



Figure 12. Fish Production Data 2017 
In the first quarter, the fish pattern did not match the production results with the results of Sumenep as the largest region. While the fish pattern shows the Bangkalan and Sampang regions. In the second and third quarters, there was no change from the first quarter where Sumenep became the dominant region. But in November the results of the fish pattern matched the production yield of 4,500 tons.

\section{CONCLUSION}

In this study, we applied several processes to determine the pattern of fish movements using satellite data from Landsat 8 . The data obtained were then pre-processed by separating the region of interest needed, namely land and sea areas. The next process is the initial segmentation of each parameter. The initial segmentation data is then combined into one (overlay) and the second segmentation is to know the position of the fish. Furthermore, predictions are made every week using Lagrange Interpolation, because the data is only per month. Predictions are made so that the pattern can be seen. Finally, the K-Means method is applied to find out the pattern, which is to cluster the prediction results. Then line the distance between centroids and lines. The results showed that the results of fish movement patterns when validated as a result had similarities in 2015. Results between fish patterns and validation data in 2015 showed similarities in January, February, March, May, June, July, August, September. In that year the pattern of movement of fish each month showed the majority of fish positions were in the Bangkalan area. This is evident from data on capture fisheries, which amounted to 22,916 tons. In 2016, results between fish patterns and validation data showed that similarities in July, August, September, and December. In 2017, results between fish patterns and validation data showed similarities in November. 2015 has the most similarities between the patterns and validation data and the least similarity are 2017.

\section{REFERENCES}

[1] Planque B, Loots C, Petitgas P, Lindstrøm U, Vaz S, Understanding what controls the spatial distribution of fish populations using a multi-model approach, Fish Oceanography, Vol. 20, No. 1, pp. 1-17, 2011.

[2] Solanki HU, Mankodi PC, Nayak SR, Somvanshi VS, Evaluation of remote-sensing-based potential fishing zones (PFZs) forecast methodology, Cont Shelf Res, Vol. 25, No. 18, pp. 2163-2173, 2005.

[3] Pillar TVR, Aquaculture principles and practice, Fishing News Books, Blackwell Science, Oxford, UK, Ed. 2, pp. 575, 2005.

[4] Fitrianah D, Hidayanto AN, Gaol JL, Fahmi H, Arymurthy AM, A SpatioTemporal Data-Mining Approach for Identification of Potential Fishing Zones Based on Oceanographic Characteristics in the Eastern Indian Ocean, IEEE Journal of Selected Topic in Applied Earth 
Observations and Remote Sensing, Vol. 9, No. 8, pp. 3720-3728, 2016.

[5] Nurdin S, Mustapha MA, Lihan T, Ghaffar MA, Determination of potential fishing grounds of Rastrelliger kanagurta using satellite remote sensing and GIS technique, Sains Malaysiana, Vol. 44, No. 2, pp. 225-232, 2015.

[6] Ruiz-Verd A, Jimenez JC, Lazzaro X, Tenjo C, Delegido J, Pereira M, et al, Comparison of MODIS and Landsat-8 retrievals of Chlorophyll- A and water temperature over Lake Titicaca, International Geoscience and Remote Sensing Symposium (IGARSS), pp. 7643-7646, 2016.

[7] Syariz MA, Jaelani LM, Subehi L, Pamungkas A, Koenhardono ES, Sulisetyono A, Retrieval of sea surface temperature over Poteran Island water of Indonesia with Landsat 8 TIRS image: A preliminary algorithm, International Archives of the Photogrammetry, Remote Sensing and Spatial Information Sciences, pp. 87-90, 2015.

[8] Badruddin, Segmentasi Citra Satelit Untuk Menentukan Potensi Budidaya Rumput Laut Di Selat Madura, D4 Final Project, EEPIS (Surabaya), 2017.

[9] Balaguru B, Ramakrishnan SS, Vidhya R, Thanabalan P, A comparative study on utilization of multi-sensor satellite data to detect Potential Fishing Zone (PFZ), International Archives of the Photogrammetry, Remote Sensing and Spatial Information Sciences ISPRS Archives, pp. 1017-26, 2014.

[10] Nybakken JW, Marine Biology: An Ecological Approach, Harpercollins College Div, Ed. 4, pp. 280-301, 2005.

[11] Ranhotra SS, Detection of Salinity of Sea Water using Image Processing Techniques, Asia-Pacific Conference on Computer Aided System Engineering (APCASE), 2014.

[12] Son YB, Gardner WD, Richardson MJ, Ishizaka J, Ryu JH, Kim SH, et al, Tracing offshore low-salinity plumes in the Northeastern Gulf of Mexico during the summer season by use of multispectral remotesensing data, Journal of Oceanography, Vol. 68, No. 5, pp. 743-760, 2012.

[13] Muhammad Fauzi, Pramaditya Wicaksono, Total Suspended Solid ( TSS ) Mapping of Wadaslintang Reservoir Using Landsat 8 OLI Total Suspended Solid ( TSS ) Mapping of Wadaslintang Reservoir Using Landsat 8 OLI, IOP Conference Series : Earth and Enviromental Science, Vol. 47, No. 1, 2016.

[14] Nguyen Hao Quang, Jun Sasaki, Hiroto Higa, Nguyen Huu Huan, Spatiotemporal variation of turbidity based on Landsat $8 \mathrm{OLI}$ in Cam Ranh Bay and Thuy Trieu Lagoon, Vietnam. Water (Switzerland), Vol. 9, No. 8, pp. 570, 2017.

[15] Chen J, Zhu W, Tian YQ, Yu Q. Estimation of Colored Dissolved Organic Matter From Landsat-8 Imagery for Complex Inland Water : Case Study of Lake Huron. IEEE Transactions on Geoscience and Remote Sensing, Vol. 55, No. 4, pp. 2201-2212, 2017. 
[16] Muhammad Syifa'ul Mufid, Tahiyatul Asfihani, Lukman Hanafi, On The Lagrange Interpolation of Fibonacci Sequence, International Journal of Computing Science and Applied Mathematics, Vol. 2, No. 3, pp.38-40, 2016.

[17] Kalyani C, Ramudu K, Reddy GR, A review on optimized K-means and FCM clustering techniques for biomedical image segmentation using level set formulation, Biomedical Research, Vol. 29, No. 20, pp. 3660-3668, 2018.

[18] S. Angel and S. Sheppard, The dynamics of global urban expansion, The World Bank, 2005.

[19] A. Nontji, Laut Nusantara, Djambatan, 1987.

[20] Y. Sakuno and H. Kunii, Chlorophyll-a estimation in Lake Shinji from Landsat-8 OLI data using Linear Combination Index (LCI) algorithm, IEEE International Geoscience and Remote Sensing Symposium, Vol. 2015, pp. 715-718, 2015.

[21] Tita Karlita, Achmad Basuki, Lakmi Makarti, Mobile Application to Identify Indonesian Flowers on Android Platform, EMITTER International Journal of Engineering Technology, Vol. 1, No. 1, pp. 96 106, 2013.

[22] Tessy Badriyah, Hybrid Modelling KMeans - Genetic Algorithms in the Health Care Data, EMITTER International Journal of Engineering Technology, Vol. 2, No. 1, pp. 63 - 74, 2014.

[23] Ali Ridho Barakbah, Kohei Arai, Centronit : Initial Centroid Designation Algorithm for K-Means Clustering, EMITTER International Journal of Engineering Technology, Vol. 2, No. 1, pp. 50 62, 2014. 